\title{
Student Teachers' Preparedness to Teach: The Case of Turkey
}

\author{
Öznur Ataş Akdemir ${ }^{1}$ \\ ${ }^{1}$ Faculty of Education, Frrat University, Elazı̆̆, Turkey \\ Correspondence: Öznur Ataş Akdemir, Faculty of Education, Fırat University, Elazı̆̆, Turkey.
}

Received: November 15, 2018

doi:10.5539/ies.v12n3p90

\author{
Accepted: December 30, 2018 Online Published: February 26, 2019 \\ URL: https://doi.org/10.5539/ies.v12n3p90
}

\begin{abstract}
In this research, it is aimed to investigate the level of student teachers' preparedness to teach in terms of different variables. To this end, a descriptive survey study is conducted with 211 undergraduate students studying at the faculty of education of a Turkish public university. The data is collected with The Preparedness to Teach Scale. Standard deviation, arithmetic mean, frequency, percentage, $t$ test, one-way analysis of variance (ANOVA), Scheffe and LSD (Least Significant Difference) test are used in data analysis procedure. According to the results, it is found that student teachers' level of preparedness to teach, understanding learner, designing effective learning environment, designing the process of teaching and technopedagogical competencies are at sufficient level. Additionally, while there isn't any difference between the levels of student teachers' preparedness to teach in terms of gender, there are some differences between them in terms of their departments and class levels. Some suggestions based on the result of the present study are directed at researchers and practitioners.
\end{abstract}

Keywords: student teachers, preparedness to teach

\section{Introduction}

The rich potential of human beings can be expanded to the highest level by the help of an education system which deals with the human beings entirely, puts the human beings in the center and arranges the contents and methods according to students. Human beings' quality, knowledge, skill and virtue depend on their education. If the societies do not provide education which is required to expand their real potential and if they don't educate their members as qualified people, these societies cannot reach the level of the developed societies. Regardless of the fact that the education programs are well-designed or the schools are equipped with the latest technologies or all the utilities of a country are mobilized for the education, none of them works without qualified teachers. In today's global information society in which the skill, virtue and the knowledge increase incrementally to create good, conscious and productive person, the importance of providing the best educational opportunities to children, the most important human resource for the future of the society, increases day by day. A decent education can only be provided by highly qualified teachers (Ereş, 2007; Özcan, 2011).

Student teachers' level of preparedness to teach is a crucial issue for their professional development. This feature which can be called as being prepared for the class in a specific perspective and being prepared for transferring the knowledge, the skill and the qualifications in a general sense, is dealt with by Göçer (2008) under following themes: planning and teaching, classroom management, communication and leadership, strategy, methods and techniques, assessment and evaluation.

The most important way of making newly appointed teachers or student teachers ready for teaching is having a well-designed and powerful teacher education programme (Wilson, Floden, \& Ferrini-Mundy, 2002). While Harris and Saas (2011) claim that teacher productivity is increased by the help of experiences which are gained through in service training; Yıldırım and Kalman (2017) claim that the basis and the starting point of being prepared to teach is pre-service teacher education period. There are some researchers who assert that teachers don't feel ready to start service and carry on service when the pre-service education is inefficient and inadequate to upskill their knowledge and competences related to real school environment (Balkar, 2014; Blomberg \& Knight, 2015; Brown, Lee, \& Collins, 2015; Eret, 2013). In another study, Stanulis, Fallon, and Pearson (2002) state that newly appointed teachers fail to identify school, class and class dynamics and they don't feel ready to teach. Liston, Whitcomb and Borko (2006) who focus on the experiences related to first years of teaching, point that teachers describe their first years as "tiring but delighted", "pessimistic but successful", "hopeful but doubtful". Additionally, those teachers participated in the study state that they experience learning to teach in these years which are defined as full of 
mixed emotions and tumult of emotions (p.351). In their research which is conducted on teacher education in terms of different education programs, Darling-Hammond, Chung, and Frelow (2002) show that the preparedness to teach levels for teachers who graduated from teaching programs are higher than for those who graduated from alternative programs. According to the results of this research, those who feel themselves prepared to teach are the ones who have teaching competence (the teachers who have pedagogic and subject matter knowledge), responsibility and vision of carrying on teaching. In the studies conducted on preparedness to teach; subject matter knowledge and pedagogical content knowledge are compared (Boe, Shin, \& Cook, 2007; Cochran, DeRuiter, \& King, 1993; Darling-Hammond, 2005).

All of the previous studies on teacher students' preparedness to teach show that there is an urgent need to conduct a research on this topic and examine both pre-service and in-service teacher education to solve the problem regarding preparedness. In this regard, the present study aims to examine student teachers' level of preparedness to teach in terms of different variables.

\subsection{The Aim of the Study}

The aim of this study is to investigate the student teachers' preparedness to teach according to different variables. To this end, following questions are tried to be answered in this study:

a) What is the level of student teachers' preparedness to teach?

b) Do student teachers' preparedness to teach levels differ according to their gender, department and class level?

\section{Method}

\subsection{Research Model}

In the present research which aims to determine the student teachers' preparedness to teach, a descriptive survey research is employed. By the help of survey model, student teachers' level of preparedness to teach, understanding learner, designing effective learning environment, designing the process of teaching and technopedagogical competencies are determined. Also, this research intends to determine whether student teachers' level of preparedness to teach, understanding learner, designing effective learning environment, designing the process of teaching and technopedagogical competencies differ in terms of variables which are classified as gender, department and class level.

\subsection{Participants}

A total of 211 student teachers studying at the faculty of education in a Turkish public university participated in the study. Of the 211 student teachers who participated in this study, 114 (54\%) of them are female students while 97 (46\%) of them are male students. In terms of department, 37 (17.5\%) of the student teachers study at Computer and Instructional Technology Teacher Education, 56 (26.5\%) of them study at Elementary Mathematics Education, 56 (26.5\%) of them study at Psychological Counseling and Guidance, $62(29,4 \%)$ of them study at Elementary Education. The class differences of the participants are as follow: 60 (28.4\%) of them are in 1st grade, $10(4.7 \%)$ of them are in 2 nd grade, $92(43.6 \%)$ of them are in 3rd grade and $49(23.2 \%)$ of these student teachers are in 4 th grade.

\subsection{Data Collection Tool}

"Preparedness to Teach Scale" developed by Darling-Hammond, Chung and Frelow (2002) and adapted to Turkish by Yildırım and Kalman (2017) is used as data collection tool of the study. Preparedness to Teach Scale consists of 20 items with five Likert-type grades and four dimensions namely preparedness to teach, understanding learner, designing effective learning environment, designing the process of teaching and technopedagogical competencies. In the reliability analysis made by Yildırım and Kalman (2017), the Cronbach alpha reliability coefficient of the scale was found .92 . In this research, the Cronbach alpha reliability coefficient is found .93 . Consequently, it can be said that Preparedness to Teach Scale is a reliable data collection tool.

\subsection{Data Analysis}

Statistical analysis of the data is conducted by SPSS 24.0. The descriptive statistical methods namely standard deviation, arithmetic mean, frequency, and percentage are used in data analysis steps. Additionally, t test, one-way analysis of variance (ANOVA), Scheffe and LSD (Least Significant Difference) tests are employed in data analysis. Significance level, also called as the critical value, or alpha level is set at the 0.05 level to test the difference between group average values. 


\section{Findings}

In this section, findings of the study are presented.

Findings related to student teachers' level of preparedness to teach and its subdimensions are given in Table 1.

Table 1. Descriptive analysis of preparedness to teach and its sub-dimensions

\begin{tabular}{lccc}
\hline Dimensions & $\mathrm{N}$ & $\mathrm{M}$ & $\mathrm{Sd}$ \\
\hline Preparedness to teach & 211 & 3.63 & .65 \\
Understanding the learner & 211 & 3.55 & .78 \\
Designing effective learning environment & 211 & 3.61 & .75 \\
Designing the process of teaching & 211 & 3.64 & .74 \\
Technopedagogical competencies & 211 & 3.71 & .76 \\
\hline
\end{tabular}

When Table 1 is examined, it can be seen that the mean of results related to student teachers' level of preparedness to teach is at sufficient level $(\mathrm{M}=3.63)$. When the findings regarding the sub-dimensions of preparedness are examined, it can be said that they are at different levels. According to these findings, it is found that undergraduate students who participated in the present study find themselves competent at the highest level $(\mathrm{M}=3.71)$ in terms of technopedagogical competencies and they find themselves competent at the lowest level $(M=3.55)$ in terms of understanding the learner.

Findings that show whether student teachers' level of preparedness to teach differ in terms of gender are given in the Table 2.

Table 2. T-test results showing the student teachers' level of preparedness in terms of gender

\begin{tabular}{|c|c|c|c|c|c|c|c|}
\hline \multirow{2}{*}{ Dimensions } & \multicolumn{2}{|c|}{ Female $\mathrm{N}=114$} & \multicolumn{2}{|c|}{ Male $N=97$} & \multirow{2}{*}{$t$} & \multirow{2}{*}{$d f$} & \multirow{2}{*}{$p$} \\
\hline & $M$ & $S d$ & $M$ & $S d$ & & & \\
\hline Preparedness to teach & 3.66 & .63 & 3.60 & .68 & .737 & 209 & .462 \\
\hline Understanding the learner & 3.60 & .80 & 3.49 & .75 & 1.010 & 209 & .313 \\
\hline Designing effective learning environment & 3.60 & .74 & 3.62 & .75 & .199 & 209 & .842 \\
\hline Designing the process of teaching & 3.71 & .70 & 3.57 & .78 & 1.425 & 209 & .156 \\
\hline Technopedagogical competencies & 3.73 & .73 & 3.68 & .79 & .488 & 209 & .626 \\
\hline
\end{tabular}

Table 2 shows that there is not statistically significant difference between student teachers' preparedness and their gender ( $p>05$ ). Considering this finding, it is obviously seen that female and male student teachers are prepared to teach at similar levels.

Findings that show whether student teachers' level of preparedness to teach differ in terms of department are given in the Table 3. 
Table 3. ANOVA results showing the student teachers' level of preparedness in terms of department

\begin{tabular}{|c|c|c|c|c|c|c|c|c|c|c|c|}
\hline Dimensions & Department & $\mathrm{N}$ & M & $\mathrm{Sd}$ & $\begin{array}{c}\text { Sources of } \\
\text { Variance }\end{array}$ & $\begin{array}{l}\text { Sum of } \\
\text { Squares }\end{array}$ & $\mathrm{df}$ & $\begin{array}{l}\text { Mean } \\
\text { Square }\end{array}$ & $\mathrm{F}$ & $\mathrm{p}$ & Difference \\
\hline \multirow{4}{*}{ Preparedness to teaching } & A & 37 & 3.73 & .57 & B. G. & 8.184 & 3 & 2.728 & \multirow{4}{*}{6.960} & \multirow{4}{*}{$.000 *$} & \multirow{4}{*}{$\begin{array}{l}\mathrm{C}<\mathrm{B} \\
\mathrm{C}<\mathrm{A}\end{array}$} \\
\hline & $\mathrm{B}$ & 56 & 3.88 & .47 & \multirow{3}{*}{ W. G. } & \multirow{3}{*}{81.139} & \multirow{3}{*}{207} & \multirow{3}{*}{.392} & & & \\
\hline & $\mathrm{C}$ & 56 & 3.35 & .64 & & & & & & & \\
\hline & $\mathrm{D}$ & 62 & 3.60 & .76 & & & & & & & \\
\hline \multirow{4}{*}{$\begin{array}{l}\text { Understanding the } \\
\text { learners }\end{array}$} & $\mathrm{A}$ & 37 & 3.59 & .65 & B. G. & 10.004 & 3 & 3.335 & \multirow{4}{*}{5.902} & \multirow{4}{*}{$.001 *$} & \multirow{4}{*}{$\begin{array}{l}\mathrm{C}<\mathrm{B} \\
\mathrm{C}<\mathrm{D}\end{array}$} \\
\hline & $\mathrm{B}$ & 56 & 3.77 & .67 & \multirow{3}{*}{ W. G. } & \multirow{3}{*}{116.955} & \multirow{3}{*}{207} & \multirow{3}{*}{.565} & & & \\
\hline & $\mathrm{C}$ & 56 & 3.20 & .70 & & & & & & & \\
\hline & $\mathrm{D}$ & 62 & 3.63 & .91 & & & & & & & \\
\hline \multirow{4}{*}{$\begin{array}{l}\text { Designing effective } \\
\text { learning environment }\end{array}$} & A & 37 & 3.73 & .75 & B. G. & 7.354 & 3 & 2.451 & \multirow{4}{*}{4.625} & \multirow{4}{*}{$.004 *$} & \multirow{4}{*}{$\mathrm{C}<\mathrm{B}$} \\
\hline & $\mathrm{B}$ & 56 & 3.81 & .55 & \multirow{3}{*}{ W. G. } & \multirow{3}{*}{109.711} & \multirow{3}{*}{207} & \multirow{3}{*}{.530} & & & \\
\hline & $\mathrm{C}$ & 56 & 3.32 & .71 & & & & & & & \\
\hline & $\mathrm{D}$ & 62 & 3.61 & .86 & & & & & & & \\
\hline \multirow{4}{*}{$\begin{array}{l}\text { Designing the process of } \\
\text { teaching }\end{array}$} & $\mathrm{A}$ & 37 & 3.65 & .63 & B. G. & 11.250 & 3 & 3.750 & \multirow{4}{*}{7.496} & \multirow{4}{*}{$.000 *$} & \multirow{4}{*}{$\mathrm{C}<\mathrm{B}$} \\
\hline & $\mathrm{B}$ & 56 & 3.98 & .55 & \multirow{3}{*}{ W. G. } & \multirow{3}{*}{103.556} & \multirow{3}{*}{207} & \multirow{3}{*}{.500} & & & \\
\hline & $\mathrm{C}$ & 56 & 3.35 & .72 & & & & & & & \\
\hline & $\mathrm{D}$ & 62 & 3.61 & .85 & & & & & & & \\
\hline & $\mathrm{A}$ & 37 & 3.90 & .66 & B. G. & 7.267 & 3 & 2.422 & & & \\
\hline Technopedagogical & $\mathrm{B}$ & 56 & 3.91 & .66 & & & & & 4410 & $005 *$ & $C<\mathrm{B}$ \\
\hline competencies & $\mathrm{C}$ & 56 & 3.49 & .73 & W. G. & 113.470 & 207 & .548 & 4.419 & $.005^{*}$ & $C<B$ \\
\hline & $\mathrm{D}$ & 62 & 3.60 & .85 & & & & & & & \\
\hline A. Computer and Instru & tional Technol & gy 1 & acher $\mathrm{E}$ & duca & & & & lementar & Mathem & tics Edu & ation \\
\hline C. Psychological Couns & ling and Guida & ice $\mathrm{F}$ & lucatio & & & & & lementar & Educati & & \\
\hline
\end{tabular}
$* \mathrm{p}<.05$.

It is apparent from this table that there are statistically significant differences between student teachers' preparedness to teach levels (including its sub-dimensions) and their departments $(\mathrm{p}<.05)$. According to Scheffe test which is conducted to determine the differences and the group relationships, it is found that preparedness to teach level of student teachers who study at Computer and Instructional Technology Teacher Education and Elementary Mathematics Education are higher than the levels of those who study at Psychological Counseling and Guidance Education department. In the dimension of understanding learner, the level of students at Elementary Mathematics Education and Elementary Education are higher than the understanding level of students at Psychological Counseling and Guidance Education. Additionally, designing effective learning environment, designing the process of teaching and technopedagogical competencies level of students who study at Elementary Mathematics Education are higher than the level of students who study at Psychological Counseling and Guidance Education.

Findings that show whether student teachers' level of preparedness to teach differ in terms of class level are given in the Table 4. 
Table 4. ANOVA results showing student teachers' level of preparedness in terms of class level

\begin{tabular}{|c|c|c|c|c|c|c|c|c|c|c|c|}
\hline Dimensions & $\begin{array}{c}\text { Class } \\
\text { Levels }\end{array}$ & $\mathrm{N}$ & M & $\mathrm{Sd}$ & $\begin{array}{c}\text { Sources of } \\
\text { Variance }\end{array}$ & $\begin{array}{l}\text { Sum of } \\
\text { Squares }\end{array}$ & $\mathrm{df}$ & $\begin{array}{l}\text { Mean } \\
\text { Square }\end{array}$ & $\mathrm{F}$ & $\mathrm{p}$ & Difference \\
\hline \multirow{4}{*}{ Preparedness to teaching } & 1. & 60 & 3.64 & .75 & B. G. & 3.347 & 3 & 1.116 & \multirow{4}{*}{2.686} & \multirow{4}{*}{$.048 *$} & \multirow{4}{*}{$3<4$} \\
\hline & 2. & 10 & 3.94 & .69 & \multirow{3}{*}{ W. G. } & \multirow{3}{*}{85.977} & \multirow{3}{*}{207} & \multirow{3}{*}{.415} & & & \\
\hline & 3. & 92 & 3.52 & .63 & & & & & & & \\
\hline & 4. & 49 & 3.79 & .50 & & & & & & & \\
\hline \multirow{4}{*}{ Understanding the learners } & 1. & 60 & 3.61 & .92 & B. G. & 7.914 & 3 & 2.638 & \multirow{4}{*}{4.587} & \multirow{4}{*}{$.004 *$} & \multirow{4}{*}{$\begin{array}{l}1<2 \\
3<2 \\
4<2\end{array}$} \\
\hline & 2. & 10 & 4.20 & .36 & \multirow{3}{*}{ W. G. } & \multirow{3}{*}{119.044} & \multirow{3}{*}{207} & \multirow{3}{*}{.575} & & & \\
\hline & 3. & 92 & 3.37 & .70 & & & & & & & \\
\hline & 4. & 49 & 3.66 & .71 & & & & & & & \\
\hline \multirow{4}{*}{$\begin{array}{c}\text { Designing effective } \\
\text { learning environment }\end{array}$} & 1. & 60 & 3.65 & .83 & B. G. & 2.342 & 3 & .781 & \multirow{4}{*}{1.408} & \multirow{4}{*}{.241} & \multirow{4}{*}{ - } \\
\hline & 2. & 10 & 3.78 & .87 & \multirow{3}{*}{ W. G. } & \multirow{3}{*}{114.723} & \multirow{3}{*}{207} & \multirow{3}{*}{.554} & & & \\
\hline & 3. & 92 & 3.49 & .76 & & & & & & & \\
\hline & 4. & 49 & 3.73 & .55 & & & & & & & \\
\hline \multirow{4}{*}{$\begin{array}{l}\text { Designing the process of } \\
\text { teaching }\end{array}$} & 1. & 60 & 3.64 & .84 & B. G. & 6.373 & 3 & 2.124 & \multirow{4}{*}{4.056} & \multirow{4}{*}{$.008 *$} & \multirow{4}{*}{$3<4$} \\
\hline & 2. & 10 & 3.90 & .77 & \multirow{3}{*}{ W. G. } & \multirow{3}{*}{108.433} & \multirow{3}{*}{207} & \multirow{3}{*}{.524} & & & \\
\hline & 3. & 92 & 3.48 & .70 & & & & & & & \\
\hline & 4. & 49 & 3.90 & .59 & & & & & & & \\
\hline \multirow{4}{*}{$\begin{array}{c}\text { Technopedagogical } \\
\text { competencies }\end{array}$} & 1. & 60 & 3.63 & .85 & B. G. & 1.764 & 3 & .588 & & & \\
\hline & 2. & 10 & 4.00 & .80 & & & & & & & \\
\hline & 3. & 92 & 3.68 & .72 & W. G. & 118.973 & 207 & .575 & 1.023 & .383 & - \\
\hline & 4. & 49 & 3.80 & .70 & & & & & & & \\
\hline
\end{tabular}

$* \mathrm{p}<.05$.

As can be seen from the data in Table 4, there is not any statistically significant difference between class level which is one of the variables and the levels of designing effective learning environment and technopedagogical competencies. On the other hand, there is statistically significant difference between class level and the preparedness to teach levels as well as the two dimensions of it namely designing the process of teaching and understanding the learners $(p<.05)$. According to LSD test which is conducted to determine the group differences, it is apparent that the preparedness to teach levels and designing the process of teaching levels of student teachers who are in 4th grade are higher than the levels of students who are in 3rd grade. Also, understanding level of students who are in 2nd grade is higher than the level of students who are in 1st, 3rd and 4th grade.

\section{Conclusion, Discussion and Suggestions}

In this study which aims to determine the student teachers' level of preparedness to teach in terms of different variables, it is found that student teachers' preparedness to teach is at sufficient level. Student teachers feel themselves competent to teach at a sufficient level. Regarding the dimensions, it is seen that while student teachers feel themselves more competent in terms of technopedagogical competences, they feel themselves less competent in terms of understanding learner. Teacher students have not yet met with students which can be a reason for their doubt related to their own adequacy of understanding learners. When the relevant literature is reviewed, it is seen that the findings of the studies conducted by Borg and Mizzi (2015), Carter and Cowan (2013), Casey and Childs (2011), Göçer (2008), Hudson and Hudson (2007), Rahman, Abdullah, and Rashid (2011), Swabey, Castleton, and Penney (2010) and Wright (2017) support the findings of the current study. Borg and Mizzi (2015), in their study conducted with teachers who have worked as teachers for one year, showed that teachers feel themselves competent in designing learning environment and in using technologies but they do not feel themselves competent in terms of dealing with the students who have challenging behaviors. Carter and Cowan (2013) found that student teachers think that they are highly competent in terms of being fair and caring all students, communicating in a respective way, and using technologies properly. In their studies conducted on the student teachers' level of preparedness to teach, Casey and Childs (2011) stated student teachers highly prepared to increase the knowledge of their students, think critically and use technologies. In the study which aims to determine the competences related to subject matter knowledge, love of human and profession, communication abilities, classroom management, planning and assessment etc. and preparedness to teach, Göçer (2008) found that student teachers are prepared to teach. In the research which investigates level of preparedness of the student teachers who study at art education, Hudson and Hudson (2007) stated that student teachers who are in the senior class feel prepared to 
teach. Rahman, Abdullah and Rashid (2011) found that Malaysian student teachers are generally prepared to teach. Swabey, Castleton and Penney (2010), who conducted a study with students of health and physics departments, found that student teachers feel themselves adequate in terms of subject matter knowledge, relationships related to teaching profession and professional practices.

Additionally, Wright (2017) found that newly appointed teachers think that they are competent in terms of preparedness to teach and they linked this to the teacher education program they graduated. On the other hand, Denessen, Bakker, Kloppenburg, and Kerkhof (2009), and Mehmetlioğlu and Haser (2013) got different findings as a result of their studies. In their studies conducted on student teachers competences of teacher-family relationship, Denessen, Bakker, Kloppenburg and Kerkhof (2009) found that their preparedness level are really low although this topic is included in their syllabus. In the research conducted by Mehmetlioğlu and Haser (2013), it was determined that student teachers who study at Elementary Mathematics Education do not think that they are highly prepared to teach. Another finding obtained in their research showed that there was no statistically significant difference between participants according to their gender. Female and male student teachers were prepared to teach at similar levels. While Mehmetlioğlu and Haser (2013) obtained similar results, Housego (1992) presented different results. Mehmetlioğlu and Haser determined that there is no statistically significant difference between participants who are students at Elementary Mathematics Education according to gender. However, Housego (1992) stated that female student teachers are more prepared to teach compared to male student teachers.

According to another important finding which is obtained as a result of this study, there is statistically significant difference between the participants in terms of the level of preparedness to teach, understanding learners, designing effective learning environment, designing the process of teaching and technopedagogical competencies. The levels of preparedness to teach of the students who study at Psychological Counseling and Guidance Education are lower than that of other students. It is possibly because of the fact that student teachers at that department less frequently involve in the classroom environment compared to the student teachers who study at other departments, they feel themselves not prepared to teach. In the study conducted by Göçer (2008), it is revealed that the preparedness to teach levels of the student teachers who study at Elementary Education and Social Sciences Education are at the sufficient level.

Lastly, it is determined that there is statistically significant difference between the participants in terms of the level of preparedness to teach, understanding learners, designing the process of teaching between class levels. Also, it is revealed that there are no differences in terms of designing effective learning environment and technopedagogical competencies. It is seen that the students who are in 2 nd grade feel more prepared to teach compared to other participants.

The implications and suggestions based on the current study can be listed as follow: Although some studies conducted on the student teachers' preparedness to teach exist in the literature, the number of these studies is not sufficient. It is possible to conduct more detailed studies on the topic. Due to the fact that the level of the student teachers' preparedness to teach related to understanding the learner, it should be ensured that student teachers come together with students more frequently during in-service education. Also, the lessons namely teaching practice and school experience should be activated more to solve this problem.

\section{References}

Balkar, B. (2014). Klinik temelli yaklaşımın bilgi alanlarını kapsayan araştırma-temelli öğretmen eğitimi politikasına ilişkin öğretmen algıları. Hacettepe Üniversitesi Ĕ̈itim Fakültesi Dergisi, 29(4), 28-45.

Blomberg, S., \& Knight, B. A. (2015). Investigating novice teacher experiences of the teaching dynamics operating in selected school communities in Finland. Improving Schools, 18(2), 157-170. https://doi.org/10.1177/1365480215576176

Boe, E. E., Shin, S., \& Cook, L. H. (2007). Does teacher preparation matter for beginning teachers in either special or general education? The Journal of Special Education, 41(3), 158-170. https://doi.org/10.1177/00224669070410030201

Borg, R., \& Mizzi, J. (2015). Year 1 teachers' preparedness for learners with different learning profiles. (Unpublished Bachelor's Degree Dissertation). University of Malta, Malta.

Brown, A. L., Lee, J., \& Collins, D. (2015). Does student teaching matter? Investigating pre-service teachers' sense of efficacy and preparedness. Teaching Education, 26(1), 77-93. https://doi.org/10.1080/10476210.2014.957666

Carter, P. J., \& Cowan, K. W. (2013). Confidence and preparedness to teach: Conflicting perspectives from multiple stakeholders. Metropolitan Universities Journal, 24(1), 47-59. 
Casey, C., \& Childs, R. (2011). Teacher education admission criteria as measure of preparedness for teaching. Canadian Journal of Education, 34(2), 3-20.

Cochran, K. F., DeRuiter, J. A., \& King, R. A. (1993). Pedagogical content knowing: An integrative model for

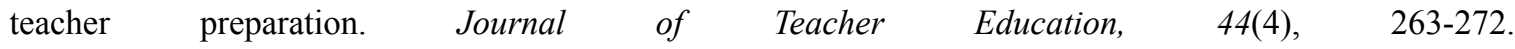
https://doi.org/10.1177/0022487193044004004

Darling-Hammond, L. (2005). Teaching as a profession: Lessons in teacher preparation and professional development. Phi delta kappan, 87(3), 237-240. https://doi.org/10.1177/0022487102053004002

Darling-Hammond, L., Chung, R., \& Frelow, F. (2002). Variation in teacher preparation: How well do different pathways prepare teachers to teach? Journal of Teacher Education, 53(4), 286-302.

Demirel, Ö., \& Kaya, Z. (2011). Eğitim bilimine giriş (6. Baskı). Ankara: Pegem Akademi.

Denessen, E., Bakker, J., Kloppenburg, L., \& Kerkhof, M. (2009). Teacher-parent partnerships: Preservice teacher competences and attitudes during teacher training in the Netherlands. International Journal about Parents in Education, 3(1), 29-36.

Ereş, F. (2007). Ĕgitim bilimine giriş. Ankara: Maya Akademi.

Eret, E. (2013). An assessment of pre-service teacher education in terms of preparing teacher candidates for teaching (Unpublished PhD Dissertation). Middle East Technical University, Ankara, Turkey.

Göçer, A. (2008). Eğitim fakültesi öğrencilerinin Türkçe öğretimi bakımından öğretmenlik mesleğine hazır bulunuşluk düzeyleri (Niğde Üniversitesi örneği). Çağdaş Eğitim Dergisi, 33(358), 5-13.

Harris, D. N., \& Sass, T. R. (2011). Teacher training, teacher quality and student achievement. Journal of Public Economics, 95(7-8), 798-812. https://doi.org/10.1016/j.jpubeco.2010.11.009

Housego, B. (1992). Monitoring student teachers' feelings of preparedness to teach and teacher efficacy in a new elementary teacher education program. Journal of Education for Teaching, 18(3), 259-272. https://doi.org/10.1080/0260747920180304

Hudson, P., \& Hudson, S. (2007). Examining preservice teachers' preparedness for teaching art. International Journal of Education \& the Arts, 8(5), 1-24.

Liston, D., Whitcomb, J., \& Borko, H. (2006). Too little or too much: Teacher preparation and the first years of teaching. Journal of Teacher Education, 57(4), 351-358. https://doi.org/10.1177/0022487106291976

Mehmetlioğlu, D., \& Haser, Ç. (2013). İlköğretim matematik öğretmen adaylarının mesleğe hazır bulunuşlukları. Pamukkale Üniversitesi Eğitim Fakültesi Dergisi, 34(2), 91-102. https://doi.org/10.9779/PUJE531

Rahman, S. B. A., Abdullah, N., \& Rashid, R. A. (2011). Trainee teacher's readiness towards teaching practices: The case of Malaysia. Paper presented at the Joint Conference UPI-UiTM 2011 Strengthening Research Collaboration on Education, Auditorium FPMIPA UPI. Retrieved from http://repository.upi.edu/operator/upload/pros_uiuitm_2011_rahman_trainee_teachers_readiness.pdf.

Stanulis, R. N., Fallona, C. A., \& Pearson, C. A. (2002). 'Am I doing what I am supposed to be doing?': Mentoring novice teachers through the uncertainties and challenges of their first year of teaching. Mentoring and Tutoring, 10(1), 71-81. https://doi.org/10.1080/13611260220133162

Swabey, K., Castleton, G., \& Penney, D. (2010). Meeting the standards? Exploring preparedness for teaching. Australian Journal of Teacher Education, 35(8), 29-46. https://doi.org/10.14221/ajte.2010v35n8.3

Wilson, S. M., Floden, R. E., \& Ferrini-Mundy, J. (2002). Teacher preparation research: An insider's view from the outside. Journal of Teacher Education, 53(3), 190-204. https://doi.org/10.1177/0022487102053003002

Wright, C. D. (2017). The effect of a teacher preparation program on teacher preparedness from the perspective of first-year teachers and their principals. Unpublished Doctoral Dissertation, Eastern Kentucky University.

Yıldırım, İ., \& Kalman, M. (2017). Öğretmenliğe hazır olma ölçeğinin Türkçe formunun geçerlik ve güvenirlik çalışması. Kastamonu Eğitim Dergisi, 25(6), 2311-2326.

\section{Copyrights}

Copyright for this article is retained by the author(s), with first publication rights granted to the journal.

This is an open-access article distributed under the terms and conditions of the Creative Commons Attribution license (http://creativecommons.org/licenses/by/4.0/). 